\title{
DOS RASTROS DO TRÁGICO EM “A PRESENÇA”, DE LYGIA FAGUNDES TELLES: HYBRIS E DESDITA
}

\section{TRACES OF THE TRAGIC IN “A PRESENÇA”, BY LYGIA FAGUNDES TELLES: HYBRIS AND MISFORTUNE}

Stela de Castro Bichuette ${ }^{1}$

\begin{abstract}
Resumo: O objetivo desse trabalho foi analisar o protagonista do conto "A presença", de Lygia Fagundes Telles (1923 -), pela via dos rastros do trágico. De forma mais específica, privilegiou-se o estudo do conceito de hybris para se entender a construção da personagem. Para tanto, no primeiro momento, o estudo fez uma incursão sobre o gênero trágico e sua aproximação com o gênero conto para, em seguida, deter-se de forma mais prolongada sobre a questão da hybris. Serviu como arcabouço teórico os trabalhos de Aristóteles (2005), Albin Lesky (2010) e Jean-Pierre Vernant (1988) no que se refere ao gênero trágico e Edgar Allan Poe (1998) e Julio Cortázar (1973) ao que se refere ao gênero conto.
\end{abstract}

Palavras-chave: A presença"; Lygia Fagundes Telles; hybris; conto; tragédia

Abstract: The protagonist of Lygia Fagundes Telles's short story "A presença" is analyzed through traces of the tragic. An investigation of the term hybris is undertaken to deepen our understanding of the construction of the character. First, the study analyzes the tragic genre and its closeness to the short story genre, with special focus on the problems concerning the term hybris. Reflections by Aristóteles (2005), Albin Lesky (2010) and Jean-Pierre Vernant (1988) foregrounded the theory of the tragic genre, whereas the works of Edgar Allan Poe (1998) and Julio Cortázar (1973) were the theoretical bases for the analysis of the short story.

Keywords: "A presença”; Lygia Fagundes Telles; hybris; short story; tragedy.

\section{Da ausência de "A presença"}

O conto "A presença", de Lygia Fagundes Telles, aparece pela primeira vez em 1977, no conjunto de Seminário dos Ratos. Essa narrativa também está presente em outras coletâneas importantes da autora como Mistérios e Os melhores contos de Lygia Fagundes Telles. Configurando-se ao lado de contos bem mais conhecidas como "As formigas", "A caçada", "A mão no ombro", esse conto não parece despertar muito interesse dos estudos literários. Em uma procura rápida na internet, encontrei apenas um único trabalho sobre ele, a dissertação Mistérios de Lygia Fagundes Telles: uma leitura sob a óptica do fantástico, de Juliana Seixas Ribeiro, defendida em 2008, na Universidade Estadual de Campinas (Unicamp). O estudo de Ribeiro (2008) faz uma pequena análise dessa narrativa, de forma rápida e dispensando a ela apenas dois parágrafos. Em

\footnotetext{
${ }^{1}$ Doutora em Letras Estudos Literários. Professora da Universidade Estadual do Centro Oeste- Unicentro, Guarapuava, Paraná.
} 
contrapartida, são inúmeros os trabalhos sobre os contos considerados mais famosos ou mais conhecidos de Lygia Fagundes Telles.

Mesmo assim, apesar de toda essa ausência, "A presença" vem despertando em mim certa inquietação desde que eu o usei pela primeira vez dentro da disciplina "Introdução aos Estudos Literários”, em 2013, com o propósito, na ocasião, de estudar junto com os alunos do primeiro ano do curso de Letras as características do conto moderno e o seu final aberto. O riso tenso e seco provocado pela história nos estudantes, me fez perceber que tinha acertado na escolha. Ficando espantados com final, em que há a insinuação de um assassinato, os alunos passaram a discutir se houve ou não uma morte planejada. Infelizmente, nós, professores, temos uma carga horária, uma ementa e um conteúdo programático que devem ser cumpridos e, por conta dessas questões burocráticas, impossibilitou-nos que, naquele momento, nos dedicássemos ainda mais tempo ao conto.

No entanto, fiquei incomodada com a narrativa. Sentia que a história ainda não estava elaborada dentro de mim e eu sempre retornava a ela. Quanto mais eu a lia, mais me interessava pelo conto e pelas personagens que, de uma maneira ou outra, vinham crescendo de forma assustadora quanto mais eu mergulhava na narrativa. Ainda que tal envolvimento não seja visto de forma positiva no universo científico, isto é, a relação sujeito-objeto poderia ficar comprometida, eu, pesquisadora da teoria do conto, era incapaz de não pensar nas tantas possibilidades que se abriam a cada leitura.

O enredo de "A presença" parece simples à primeira vista e um leitor mesmo experiente pode o ler apenas sob o invólucro de uma narrativa interessante que deixa um vazio no final por não apresentar aquele desfecho fechado clássico. A narrativa, assim, gira em torno de um hotel habitado apenas por idosos e que, em um dia qualquer, recebe como hóspede um jovem de vinte e cinco anos. O jovem foi recepcionado pelo velho porteiro que tentou de todas as formas possíveis dissuadir o rapaz de hospedar-se ali, afirmando categoricamente que os velhos não iriam gostar daquela presença incômoda e fariam todo o possível para expulsá-lo do lugar. O moço não leva muito a sério os conselhos do porteiro. No entanto, a cena final do conto sugere que o recém-chegado poderia ter sido envenenado durante o jantar pela comunidade de velhos. Assim, tem-se no final: "Achou um certo amargor na goiabada com queijo. Ao se deitar, depois de ter tomado o chá servido às vinte e uma horas, ele já não se sentia bem" (TELLES, 2007, p. 121). 
Por essa linha de análise, em "A presença", a atmosfera de mistério compactua por esconder uma história de perseguição que culminará, no que se defende aqui, no assassinato do protagonista pela comunidade de velhos que habita o velho hotelmausoléu, espaço do conto. Assim, o recorte literário da realidade exigido pela forma breve caminha pari passu em dois sentidos. Um sentido objetivo: a parada de um jovem em um hotel de velhos e, um sentido existencial, mais amplo, que sugere 0 questionamento sobre a infinita fragilidade da existência humana. Esse último sentido revelará um leque de significações muito mais abrangente do que uma narrativa misteriosa e objetiva, que pode ser caracterizada por ter presente toda uma gama de elementos inesperados e sombrios que faz lembrar o ambiente gótico.

A imagem dual, velho-moço, parece remeter de forma espetacular ao estranhamento experimentado pela comunidade de velhos, assombrada pela juventude e pela vida perdida, personificada agora no jovem hóspede. Será essa juventude que espanta, que amedronta, o tema central da narrativa. Os velhos, aterrorizados pela presença perturbadora, não se reconhecem mais no jovem que um dia foram, fazendo desse assombro o conflito dramático do conto. A força desse confronto silencioso é encoberta pela aparente situação de fragilidade e ruína dos velhos, presenciada desde o princípio do enredo pelo jovem. A presença incômoda da juventude levará a comunidade de velhos, como se viu no desfecho, a optar pela exclusão dela de forma definitiva. O que não deixa de provocar uma sensação estranha e incômoda também no leitor.

No elucidativo ensaio "O Estranho", Sigmund Freud (1976, p.275) explica que esse sentimento está relacionado "indubitavelmente com o que é assustador - com o que provoca medo e horror." Ainda definido o termo, o psicanalista ensina que no conceito de estranho contém a ideia da repetição, ou "algo reprimido que retorna" (FREUD, 1999, p. 55, grifo do autor). Dessa forma, há o estranhamento quando algo se repete e, por isso, "o estranho é aquela categoria do assustador que remete ao que é conhecido, de velho, e há muito familiar" (FREUD, 1976, p. 277). Diante disso, fica manifesto que erra quem pensa que o estranho se faz presente quando há novo ou por algo que não é familiar.

Para Freud (1976), então, o estranho está relacionado a "algo que é familiar e há muito estabelecido na mente, e que somente se alienou desta através do processo de repressão [...] o estranho como algo que deveria ter permanecido oculto mas veio à luz" (FREUD, 1976, p. 301, grifo meu). Diante dessa perspectiva mais psicanalítica do conto, a comunidade de velhos se depara com o retorno da juventude perdida que Ihes foi familiar em algum momento de suas vidas. No entanto, no momento presente, a mocidade do 
jovem parece estranha aos velhos quando eles se deparam com ela. Estando agora envelhecidos, os hóspedes lidam com a juventude de forma a reprimi-la, isolando-se da sociedade ou tirando todos os espelhos para esconder a passagem do tempo. Infelizmente para eles, os mecanismos de defesa, usados para reprimir o pensamento da comunidade sobre a proximidade da morte, volta com força letal e esmagadora com a chegada do jovem. Dessa forma, "a repetição indubitavelmente provoca uma sensação estranha, que, além do mais, leva a sensação de desamparo” (FREUD, 1999, p.305).

É permitido também considerar "A presença" como uma narrativa estranha nos moldes propostos pela definição do gênero fantástico, dentro de uma perspectiva da teoria da literatura, feita por Tzvetan Todorov (2012), em Introdução à Literatura Fantástica. Para Todorov (2012), as narrativas que podem ser classificadas como estranhas são aquelas que embora não apresentem nenhum acontecimento que não possa ser explicado pela razão, trazem em seu bojo aspectos "que são de uma maneira ou de outra, incríveis, extraordinários, chocantes, singulares, inquietantes, insólitos e que, por essa razão, provocam na personagem ou no leitor reação semelhante àquela que os textos fantásticos nos tornaram familiar" (TODOROV, 2012, p. 53).

O estranho dentro do conto, pelo viés de Todorov (2012), faz-se notar no momento no qual o leitor depara-se com uma situação inusitada, a saber, velhos aparentemente indefesos que constroem em segredo um assassinato. Essa situação provoca horror e surpresa pois velhinhos indefesos em asilos não correspondem à ideia de assassinos implacáveis. A presentificação da juventude perdida na figura do moço ocasiona o horror e o estranhamento também na comunidade de velhos uma vez que os aproxima, como dito, da possibilidade da morte iminente. Todos esses elementos que provocarão um efeito de estranhamento serão construídos pelo recurso da inversão ou do que se pode chamar de história cifrada, nos moldes falado por Ricardo Piglia (2004), em Formas Breves, que, aqui, de algum modo, coloca o leitor em contato com o insólito.

Assim, de todas essas minhas inquietações, primeiramente surgiu a curiosidade de saber o motivo pelo qual esse conto não merecia atenção tendo em vista as poucas referências de estudo destinados a ele. Feita, então, a rápida pesquisa que me levou à dissertação mencionada, decidi, eu mesma, quase de maneira pioneira a estudar essa narrativa. Por esse caminho, o meu primeiro trabalho sobre "A presença" foi feito por duas perspectivas, nem tão pioneiras assim dentro dos estudos sobre a prosa de Telles: a da teoria do conto e das narrativas de horror e mistérios oriundas do gênero gótico. 
Desse estudo preliminar, um importante ponto foi levantado sobre "A presença", qual seja, o papel do recorte, procedimento indispensável para a construção das formas breves. Julio Cortázar (1973), em Valise de Cronópio, ao estabelecer a diferença entre os gêneros romance e conto, serve-se do recorte para a distinção dos gêneros, posto que o conto parte da noção de limite, sem que se esgote a sua matéria enquanto significação. Então, para que o conto não perca enquanto significação devido ao seu recorte restrito, é necessário que "ao recortar o fragmento de realidade, fixar determinados limites, mas de tal modo que esse recorte atue como uma explosão que abra par em par uma realidade muito mais ampla (CORTÁZAR, 1973, p. 151).

Dessa forma, da mesma maneira que as ementas e cronogramas têm um prazo a para ser cumpridos, os periódicos especializados, por questão de limite, também têm normas de tamanho que devem ser obedecidas. Por esse motivo, ainda que o universo do recorte contístico não se esgota nele mesmo, os artigos precisam, em algum momento, de um ponto final ainda que o autor queira ir mais além. É por isso que o objetivo desse trabalho vai girar em torno de um dos vários campos de significação abertos pela escolha de um recorte tão significativo por parte Telles. Assim, esse estudo de "A presença" desdobra-se a trilhar os rastros do trágico dentro dessa narrativa e, mais especificamente, a construção da hybris da personagem protagonista, o jovem hóspede.

\section{Das tragédias clássicas, do gênero conto, das personagens}

Já se foi dito, dentro dos estudos de teoria literária, que há muitas semelhanças entre a estrutura da tragédia, postuladas por Aristóteles na Poética e as regras de composição elaboradas no século XIX por um dos mestres da arte contística, Edgar Allan Poe. Ao comparar a estrutura do conto e da tragédia, percebe-se que o diálogo entre os dois gêneros é possível se se pensar em conceitos como limite, extensão, unidade, personagens, clímax.

Ao falar sobre a extensão da tragédia, Aristóteles (2005, p.27), no capítulo VII, da Poética, afirma que em qualquer coisa, ordenada em partes, deve haver uma determinada extensão e que as fábulas, entendidas como histórias, devem ter "uma extensão que a memória possa abranger inteira" e, ainda, que sua "duração deve permitir aos fatos suceder-se, dentro da verossimilhança ou da necessidade, passando do infortúnio à ventura, ou da ventura ao infortúnio; esse é o limite de extensão conveniente" (ARISTÓTELES, 2005, p.27, grifo meu). N’A filosofia da composição, Poe (1999) também 
admite que a extensão é peça primordial na feitura de uma obra. Para o contista americano, "se uma obra de arte é longa demais para ser lida de uma sentada, devemos resignar-nos a dispensar o efeito imensamente importante que se deriva da unidade de impressão" (POE, 1999, p.103, grifo meu).

Dessas citações sobre a extensão da fábula tanto para Aristóteles (2005) quanto para Poe (1999), origina um outro conceito caro ao dois: o de unidade. Para o filósofo grego, a unidade está condensada em uma ação única, ou seja, um único assunto. Como explicação, vale-se tanto da Odisseia quanto da llíada, ambas atribuídas a Homero, para comprovar que nas duas os fatos giram em torno de uma ação única, a saber, a volta do herói Ulisses para casa e os eventos da Guerra de Troia, respectivamente. Dessa forma,

é preciso que a fábula, visto ser uma imitação duma ação, ou seja, duma única e inteira, e que suas partes estejam arranjadas de tal modo que, deslocando-se ou suprindo-se alguma, a unidade seja aluída e transformada; com efeito, aquilo cuja presença ou ausência não traz alteração sensível não faz parte nenhuma do todo.(ARISTÓTELES, 2005, p.28, grifo meu).

Poe (1999) também dá importância ao elemento da unidade dentro do conto, ligando-o ao conceito de duração para, posteriormente, atrelá-lo a duas outras noções: a de efeito e a de brevidade.

A duração de extensão de "uma sentada" está intimamente ligada à unidade e, consequentemente, ao efeito. Segundo Poe (1999, p. 105) se uma obra ultrapassa esse limite, qual seja, o de ser lida de uma vez só, o efeito dela no leitor não seria a de uma unidade única pois, se requer "duas sentadas, os negócios do mundo interferem e tudo o que se pareça com totalidade é imediatamente destruído". Há de se ressaltar, no entanto, que ao conceituar o elemento de unidade não se deve cometer o erro já antecipado por Aristóteles (2005, p.27) de que a unidade da fábula não consiste, "como creem alguns, em ter um só herói, pois a um mesmo homem acontecem fatos sem conta, sem deles resultar numa unidade. Assim, uma pessoa, pratica muitas ações, que não compõem nenhuma ação única". Poe (1999, p.103), ao discutir sobre esse ponto, propõe que "resta ver se há, na extensão, qualquer vantagem que contrabalance a perda da unidade resultante", e garante: "Digo logo que não há".

Seguindo nas suas considerações, Aristóteles (2005, p.p.24) afirma que a tragédia deve ser "uma representação de uma ação grave, de alguma extensão e completa [...] a qual inspirando pena e temor, opera a cartase própria dessas emoções". Para Poe (1999), a questão da extensão e do desfecho também obrigatoriamente devem ser elementos de 
cuidado para o contista, que precisa levar em consideração, ao construir a narrativa, o que ele chama de "efeito" cuja definição contém pontos de contato com o efeito catártico proposto por Aristóteles. Por essa via de argumentação, Poe (1999, p.103) afirma que em um poema extremamente longo, o "conjunto se vê privado, por sua extrema extensão, do vastamente importante elemento artístico, a totalidade, ou unidade de efeito".

Outro ponto importante para se atingir o objetivo que se propôs, a saber, a presença da hybris, como elemento causador da ruína da personagem do conto de Telles, é, obviamente, a questão da personagem. No capítulo XIII, da Poética, Aristóteles (2005) apresenta sua teoria de como deveriam ser as personagens mostradas na tragédia. Desse ensinamento é que vem a máxima conhecida de que não se deve mostrar homens honestos passando de felizes a infelizes, pois isso inspira indignação; muito menos representar sujeitos vis passando da infelicidade à fortuna, pois seria o que há de menos trágico e, nem mesmo os perversos deveriam ser mostrados passando do infortúnio à felicidade, pois não despertaria tampouco compaixão ou temor.

Por isso, o herói deve estar em "situação intermediária; é aquele que nem sobreleva pela virtude e justiça, nem cai no infortúnio em consequência de vício e maldade, senão de algum erro, figurando entre aqueles que desfrutam grande prestígio e prosperidade; por exemplo, Édipo, Tiestes e homens famosos de famílias como essa" (ARISTÓTELES, 2014, p.32). Diante disso, a passagem da felicidade ao infortúnio não deve resultar do fato da personagem ser má ou merecer tal destino, mas sim, por cometer um erro, harmatia, na ignorância por conta de um orgulho exacerbado que vem a ser a hybris do herói.

Ao se pensar em "A presença", a personagem central, que aqui se admite ter sido assassinada pela comunidade de velhos, serve de exemplo de herói que comente o erro na ignorância, muitas vezes por conta de um orgulho desmedido e, por conta desse desconhecimento, acaba caindo em desgraça. No conto, durante todo o dia, o rapaz recém chegado ao hotel ri desdenhosamente quando dos conselhos do velho porteiro para que deixasse aquela hospedaria, uma vez que o grupo dos velhos habitantes fariam qualquer coisa para expulsá-lo dali.

Talvez não tivesse sido suficientemente claro, talvez, mas o fato é que se ele não se importava com a presença dos velhos, era bem provável que os velhos se importassem (e quanto!) com a sua presença. Tão fácil entender, como um jovem assim sagaz não entendia? Os velhos formavam uma comunidade com seus usos e costumes. Uniram-se e a antiga fragilidade, tão agredida além daqueles portões, foi se transformando numa força. Num sistema (TELLES, 2007, p.117). 
Nesse outro trecho também se percebe o desdém altissonante do rapaz frente aos apelos do velho porteiro:

\begin{abstract}
Arqueou as sobrancelhas fatigadas: será que amigo não percebia que ia ser importuno? Um intruso? Representava o direito do avesso. Ou o avesso do direito? O problema é que ele, um simples porteiro, não podia sequer defendê-lo se a comunidade de velhos decidisse sutilmente pela sua exclusão. Por mais tolos que esses velhos pudessem parecer, guardavam o segredo de uma sabedoria que se afiava na pedra da morte. [...] até onde poderia chegar o ódio por aqueles que viera humilhá-los, irônico, provocativo, tumultuando a partida? O jovem se animara com a ideia da piscina. (TELLES, 2007, p.119, grifo meu).
\end{abstract}

Assim, como o velho cego Tirésias tentara dissuadir o jovem e inteligente Édipo de procurar pelo assassino de Laio, o porteiro do hotel tenta alertar o jovem que a sua permanência dentro do local causaria sua ruína. Com motivos bem menos nobres do que o herói grego, o herói moderno está mais preocupado com seus próprios interesses e desejos. As palavras do porteiro que teme pela vida do hóspede são interrompidas pelo narrador que displicentemente conta que o protagonista a despeito de todos os temores e avisos, se interessa pela piscina do hotel.

Por tudo isso, não é temerário afirmar que existe pontos de contato entre o conto com as antigas e clássicas tragédias do mundo helênico, principalmente se se pensar nos elementos estruturais o que se chamou aqui de rastros do trágico. Tais rastros são evidenciados tanto naquilo que diz respeito à obediência formal do gênero trágico comparado ao gênero conto quanto quando há a incorporação dos elementos estruturais da tragédia clássica à narrativa moderna. Por fim, mais uma vez a título de aproximação entre os dois gêneros, tem-se, portanto, a duração dos acontecimentos narrados em apenas um único dia o que, sem dúvida, remente ao período solar, postulado por Aristóteles.

\title{
3. O jovem hóspede: da hybris à desdita
}

Albin Lesky (2010), em A tragédia grega, discute que é no já citado capítulo XIII da Poética, que Aristóteles desenvolve a teoria da mudança do destino como núcleo do mito mágico e "em conexão com ela, [Aristóteles] defende sua concepção de caracteres 'médios' como sendo os mais apropriados à tragédia, Aristóteles diz que semelhante queda no infortúnio [...] não deve decorrer de um defeito moral [...]e se refere como uma 
'falha' no sentido da incapacidade humana de reconhecer aquilo que é correto e obter uma orientação segura" (LESKY, 2010, p.29). É nesse sentido que se quer pensar a postura do protagonista do conto frente às adversidades que enfrentará até a sua queda, o possível assassinato.

A personagem-jovem, não nomeada, não reconhece aquilo que deve fazer para não cair no infortúnio. Assim, o protagonista deveria compreender as palavras do porteiro quando tentava alertá-lo para a possibilidade da desventura, pegar o carro e abandonar o hotel-mausoléu. Ao invés disso, mantém a postura altiva de nunca duvidar que não seria capaz de lidar com velhos frágeis e indefesos. Vejamos como isso funciona na narrativa:

Mas aos poucos os hóspedes mais velhos foram dominando à medida que os mais jovens começaram a rarear, não sabia explicar o motivo, o fato é que a transformação - embora lenta - fora definitiva. Um hotel-mausoléu. Que jovem podia se sentir bem num hotel assim? Se ele prosseguisse pela mesma estrada por onde viera, alguns quilômetros adiante encontraria um hotel excelente, tinha várias setas indicando o caminho, ficava num bosque bastante aprazível. E pelo que ouvira contar o ambiente era alegre, jovial (TELLES, 2007, p.116).

Por esse caminho, o porteiro já sugere que algo aconteceu no hotel para que os jovens se afastassem dele; no entanto, o recém-chegado parece nem mesmo notar que pudesse correr algum tipo de perigo e nem reconhece que o porteiro lhe dá dicas ou pistas de que algo sombrio acontece no hotel, ao deixar subentendido que os jovens que por ali se hospedavam não foram muito bem vindos. E será essa a falha trágica do jovem, não tomar conhecimento de que não praticava uma ação correta ao permanecer como hóspede naquele lugar, a responsável por sua queda. Dessa forma, Lesky (2010) convida para uma reflexão bastante pertinente quando questiona se as considerações de Aristóteles no que diz respeito ao fato de que o homem não tomba por um defeito moral mas afunda devido ao fato de que a natureza humana não está à altura de determinadas situações.

As nuanças trágicas dentro de "A presença" muitas vezes, por motivos óbvios, operam de forma contrária aos pressupostos das tragédias helênicas clássicas. Isso fica bastante claro quando se pensa que "o sujeito trágico, o que está enredado num conflito insolúvel, deve ter alçado à sua consciência de tudo isso e sofrer tudo conscientemente (LESKY, 2010, p.34, grifo do autor). Neste ponto, portanto, o que se tem é o afastamento do herói clássico do herói moderno do conto, ou seja, conquanto o protagonista aja de forma orgulhosa que o levará à desdita, seu sofrimento só será percebido pelo leitor do conto. 
A desventura do jovem hóspede não será conhecida por ele mesmo, não haverá o reconhecimento nos moldes aristotélicos. Aristóteles (2010) aponta que se pode ter quatro tipos de reconhecimento: por meio de sinais, por meios forjados pelo próprio poeta, por meio de uma lembrança e "o melhor de todos os reconhecimentos é o decorrente das ações mesmas, produzindo-se a surpresa por meio de sucessos plausíveis" (ARISTÓTELES, 2014, p. 36). De forma completamente oposta, o protagonista do conto não percebe sua falha e a peripécia de sua existência não terá a gama de sofrimento exigida na tragédia clássica como acontece com Édipo ou Antígona, uma vez que para "uma vítima sem vontade e que conduzida surda e muda ao matadouro não há impacto trágico" (LESKY, 2010, p. 34).

Por outro lado, o leitor moderno se relaciona com o trágico do conto de maneira diferente do público das tragédias estudadas por Aristóteles. Ao não reconhecer seu fim de forma ligada a suas más escolhas, a personagem do conto se iguala aos seus leitores de forma que as desventuras sofridas pelo homem moderno não têm o impacto, no sentido que elas têm e são sentidas pelos heróis gregos. Mas mesmo assim, o herói moderno do conto desventura-se na vida de modo cego, tal como Édipo, pensando que está no comando, enquanto contingências externas, que podem ser políticas ou sociais, são as que, muitas das vezes, realmente impulsionam o seu destino.

Assim, no decurso desse dia no hotel, o herói moderno do conto acredita que está no controle de sua vida, ignorando completamente que por trás das portas envelhecidas do lugar seu assassinato está sendo planejado. Ao se deparar com essa revelação, o leitor se percebe, tão ignorante quanto a personagem do conto o é, e mais, se percebe assustadoramente alheio à impossibilidade de ter a almejada autonomia moderna. De posse disso, o que vem à tona é o horror da realidade e a compaixão por eles mesmos. Nesse ponto, a tensão criada pela contista na construção do enredo produz o efeito catártico falado por Aristóteles.

Enfim, dentro da narrativa, essa situação pode ser entendida no simples fato de que os velhos do hotel tramam o assassinato, ou seja, tomam nas mãos as rédeas do destino do rapaz que, inocentemente, por seu orgulho e crença em si mesmo, pensa que tem a autoridade sobre a sua situação.

Tirou a garrafa de uísque da mala. Ligou o rádio.

Quando subiu ao trampolim, notou um vulto que espiava atrás da cortina rendada de uma das janelas. Baixou o olhar divertido para a água de um verde profundo, onde as folhas boiavam num ondulado calmo. Abriu os braços. Saltou. Enquanto nadava de costas, entreviu uma cabeça branca na fresta de uma janela do primeiro andar. Logo apareceu outra cabeça 
(de homem?) que ficou um pouco atrás, na sombra. Chegou-lhe vagamente o fiapo triturado de uma discussão antes que a janela se fechasse com força. Ele deitou-se no banco de pedra e ali ficou de braços pendentes, a tanga vermelha escorrendo água, os olhos cerrados. (TELLES, 2010, p.121).

Essa crença orgulhosa que se está no controle absoluto dos acontecimentos pode ser entendida na tragédia clássica como hybris. Deve-se relacionar esse conceito imediatamente a um outro que também faz parte do universo do trágico, a harmatia. É por sua hybris que herói trágico comete a harmatia, caindo assim na desventura. Trilhando os passos propostos por Juanito de Souza Brandão (2009), em Teatro Grego - tragédia e comédia, fica entendido que no mundo ático, as correntes religiosas populares almejam em último sentido a imortalidade. No entanto, é nesse desejo que reside o choque entre os anseios da religião popular "com a religião oficial e aristocrática da pólis, cujos deuses olímpicos estavam sempre atentos para esmagar qualquer 'démesure' (desmedida) de pobres mortais que aspirassem a imortalidade" (BRANDÃO, 2009, p. 11).

Os deuses, portanto, sentiam-se ameaçados nos seus tronos olímpicos do mesmo modo que o estado temia pela desestruturação da ordem por conta da liberdade "de certos condicionamentos e de interditos de ordem ética, política e social. Assim, se explicam tantos 'avisos' na Grécia antiga, concitando todos à moderação” (BRANDÃO, 2009, p.11). Será na desobediência à temperança e à prudência que o erro trágico advindo da hybris do herói irá se concretizar.

O rastro do trágico perseguido nesse trabalho é exemplificado pela figura do jovem hóspede que cheio de entusiasmo e de êxtase ultrapassa os limites dos interditos, a saber, que aquele local era destinado aos velhos e que jovens, ainda que no regulamento do hotel não tivesse nenhuma proibição quanto ao limite de idade dos que ali se hospedam, não eram bem vindos. Os avisos do porteiro serviriam para estipular uma certa norma operativa de ordem social dentro do hotel.

Reside, então, segundo Brandão (2009) na passagem do métron, que pode ser entendido como a medida de cada um, para a desmesura, ou seja, a hybris. Isto posto tem-se que a hybris "é uma violência feita a si próprio e aos deuses imortais, o que provoca a 'némesis', o ciúme divino: o ator, o herói, torna-se êmulo dos deuses. A punição é imediata: contra o herói é lançada, 'áte', cegueira da razão” (BRANDÃO, 2009, p.11). Assim sendo, tudo que o herói fizer, sob influência da desmedida, fará contra si mesmo, ou como ensina Brandão (2009, p.10) "mais um passo e fechar-se-ão sobre eles as garras da 'Moira', o destino cego". Para finalizar, Brandão (2009, p.12) continua dizendo 
que está "aí o enquadramento do trágico: a tragédia só se realiza quando o métron é ultrapassado. No fundo, a tragédia grega, como encenação religiosa, é o suplício do leito de Proscrusto contra todas as démesure.

Em "A presença", o jovem destemido, ultrapassa o métron, a ponderação, a moderação e a racionalização das atitudes, o que o leva imediatamente ao cometimento da hybris. Então, o recém-chegado acredita que a sua juventude, sua força e vitalidade poderiam afastá-lo de todo o mal que por ventura pudesse aparecer no caminho, a eterna prepotência juvenil do desafio do perigo. Desafiando a ordem estabelecida no hotel, o jovem gera ciúmes na comunidade de velhos que ao se deparar com a desmedida do rapaz, resolve expulsá-lo da convivência através do possível assassinato. Essa ação punitiva, explica, Brandão (2009, p.12), "é o ciúme divino, pois que o mortal em hybris, após ultrapassar o métron, é de certa forma um competidor, um êmulo dos deuses. $\mathrm{O}$ castigo é imediato: áte, a cegueira da razão, se apossa do pobre mortal. Tudo que este fizer, fá-lo-á em direção ao abismo final, a queda fatal nos braços da Moira".

Torna-se interessante analisar o conto por esse viés trágico, pois ao mesmo tempo que se percebe uma aproximação do trágico clássico vê-se, também, a inversão desses elementos. Ora, se o jovem rapaz caiu em desgraçada por conta da hybris; a comunidade de velhos o puniu não por ele querer a imortalidade mas por ele representar a proximidade da mortalidade para eles. No sentido oposto, o jovem foi punido não por se aproximar da velhice mas por ser fonte permanente de lembranças de que a morte era inevitável, não haveria como escapar dela. Aos moldes do que foi demonstrado por Freud (1976) anteriormente.

Prosseguindo, como se falou que o conceito de hybris vem atrelado ao de harmatía, o erro ou a culpa trágica, no capítulo XII, da Poética, Aristóteles explica que o trágico se concretiza quando a passagem da condição de fortuna para a desventura se dá por uma falha. Tal erro não deve ser tomado como uma falha de caráter ou falha moral, Lesky (2010, p.44) ao explicar o que seria essa falha, salienta que devemos entender a "falha trágica" como uma "falha intelectual do que é correto, uma falta de compreensão humana em meio dessa confusão em que se situa nossa vida".

Assim, o jovem hóspede - "nem moralmente perfeito nem reprovável" (LESKY, 2010, p.43) - ao não dar ouvidos aos avisos insistentes do porteiro por conta de sua confiança demasiada em si mesmo, hybris, cai em desventura por não ser capaz de usar de sua inteligência intelectual, responsável por afastá-lo do perigo. Ao ficar cego diante do que é apresentado a ele, acontece a falha trágica, harmatía. 
Já não sorria quando examinou os documentos do recém-chegado. Devolveu-os. Os olhos de um azul-pálido estavam frios. Talvez não tivesse sido suficientemente claro, talvez, mas o fato é que se ele não se importava com a presença dos velhos, era bem provável que os velhos se importassem (e quanto!) com a sua presença. Tão fácil entender, como um jovem assim sagaz não entendia? (TELLES, 2007, p.117, grifo meu).

Ao final da narrativa, entretanto, não acontece o que tradicionalmente Aristóteles chamou de peripécia e de reconhecimento. Para o filósofo, "peripécia é uma reviravolta das ações em sentido contrário" e o "reconhecimento, como a palavra mesmo indica, é a mudança do desconhecido ao conhecimento" (ARITÓTELES, 2014, p.30).

Não é permitido falar então em reconhecimento e peripécia nos moldes ensinados por Aristóteles simplesmente porque se tem um grande espaço de tempo que separa a tragédia ática da narrativa breve do século XX. O conto, como já mostrado, embora pague algum tributo à teoria do filósofo grego obviamente não pode ser inteiramente comparado a ela uma vez que são de épocas e de mundos diferentes. No conto, somente cabe ao leitor uma suposta predição do fim que levará a personagem central.

Dessa forma, não se vê o modelo clássico de reconhecimento, ou seja, o momento em que o herói reconhece seu erro trágico, harmatía, e, ao tomar conhecimento dele, cai no infortúnio, na desdita. O fato é que longe do drama vivido por Édipo ou Antígona, o narrador de "A presença", aponta o fim trágico imperceptível para o protagonista que, quase bobamente, acredita estar passando mal por algo que não Ihe caiu bem no jantar.

No jantar, antes mesmo de provar a comida, despejou o sal, o molho inglês, a pimenta e bateu palmas vigorosas para os três velhos músicos um pianista, um violinista e o careca do rabecão - que tocaram antigas peças que alguns hóspedes (poucos desceram para o jantar) ouviram imperturbáveis. Achou um certo amargor na goiabada com queijo.

Ao se deitar, depois de ter tomado o chá servido às vinte e uma hora, ele já não se sentia bem (TELLES, 2007, p.119).

Como se pode perceber pelo trecho acima, o destino infeliz que poderia estar próximo permanece aberto ao final do conto. Na verdade, nada realmente indica que haverá um assassinato, podendo ser permitido até pensar que na verdade fora algo na refeição que não tinha feito bem ao rapaz. Por outro lado, não dá para negar, tendo em vista, todas as pistas deixadas pelo narrador e toda a preocupação do velho porteiro, de que algo muito estranho estava para acontecer. Os avisos do porteiro contrastam vigorosamente com o comportamento orgulhoso e despreocupado do jovem rapaz. Notase que no trecho final, citado acima, a atitude espalhafatosa do hóspede "batendo palmas 
vigorosas" demonstra que as palavras de advertência não surtiram nenhum tipo de efeito no moço o que inevitavelmente colabora para o seu fim infeliz.

Parece possível, portanto, verificar os traços do trágico mais uma vez no conto através do que se chama de ironia trágica. Em "Tensões e ambiguidade na tragédia grega", Jean-Pierre Vernant (1988), enfatiza o conceito de opacidade, ou de vocabulário opaco. Tal conceito dialoga com o de alienação intelectual por parte do herói, proposto por Lesky (2010).

Isso aponta para o fato, ainda de acordo com Vernant (1988, p.35), que dentro da ambientação cênica, os diálogos "têm menos a função de estabelecer a comunicação entre as diversas personagens que a de marcar os bloqueios, as barreiras, a impermeabilidade dos espíritos, a de discernir os pontos de conflito". Assim, no ambiente do hotel, as palavras trocadas entre o hóspede e porteiro nada têm de uma comunicação efetiva na troca de informações. O que se vê claramente é a zona de opacidade entre ambas as personagens uma vez que cada personagem permanece fechada em seu próprio mundo. Nesse ponto de incomunicabilidade é que Vernant $(1988$, p.35) apresenta a noção de ironia trágica.

A ironia trágica poderá consistir em mostra como, no decurso do drama, o herói cai na armadilha da própria palavra, uma palavra que se volta contra ele trazendo-Ihe a experiência amarga de um sentido que ele obstinava não conhecer. [...] É apenas para o espectador que a linguagem do texto pode ser transparente em todos os níveis na sua polivalência e ambiguidade. Do autor ao espectador, a linguagem recupera essa plena função de comunicação que tinha perdido em cena, entre as personagens do drama. Mas o que a mensagem trágica comunica, quando compreendida, é precisamente que, nas palavras trocadas pelos homens, existem zonas de opacidade e de incomunicabilidade.

Desse enxerto, não é temerário levar em consideração três pontos que merecem destaque para finalizar o quanto a hybris do jovem hóspede contribui para o seu fim que poderá ser infeliz. O primeiro diz respeito a parte em que Vernant (1998) reporta ao fato de que o herói cai na armadilha da própria palavra, ora, durante todo o percurso narrativo, o jovem hóspede não ouve aquilo deveria ouvir para se livrar da desdita que se aproxima. Através da ironia, debocha das atitudes dos velhos do hotel, ou seja, não acredita que possam the fazer mal. São pequenas pistas oportunizadas pelo narrador nas quais deixam se entrever o desdém sútil do jovem pelos conselhos preocupados do porteiro: "queria um apartamento nesse hotel e só não insistiria se o regulamento tivesse uma cláusula que proibisse que proibisse um jovem de vinte e cinco anos de se hospedar ali"; adiante: "Ele acendeu um cigarro e ofereceu outro ao porteiro que agradeceu, não podia 
fumar"; em seguida, "O jovem se animara com a ideia da piscina; para terminar: "Tirou a garrafa de uísque. Ligou o toca disco".

Merece ser discutido também a menção que Vernant (1988) faz de que é somente para o espectador que a mensagem pode ser transparente em qualquer um dos níveis. No caso da narrativa, troca-se o espectador pelo leitor que, através das pistas e vazios deixados pelo narrador, consegue enxergar muito mais além do que as personagens. Então, as insinuações constantes, de que algo poderia dar errado se o recém-chegado continuasse no hotel, feitas pelo aterrorizado porteiro encaixa-se nessa zona nebulosa para o protagonista. Ao mesmo tempo que para o leitor, o temor do porteiro começa a fazer um sentido maior e ele, agora receoso, não acha muita graça na preocupação do velho, muito pelo contrário, acaba se solidarizando com o velho guardião.

Os avisos feitos pelo porteiro que o narrador acentua na forma de escrita em itálico faz diferença para o leitor. Tem-se da descrição do narrador para as ações do porteiro: "Forçou o sorriso paternal, disfarçando o espanto com uma cordialidade exagerada, mas o jovem queria um apartamento? Ali, naquele hotel?!; outra vez: "Um museu mausoléu. Que jovem poderia se sentir bem num lugar assim?"; e, por último:

Por mais tolos que esses velhos pudessem parecer, guardavam o segredo de uma sabedoria que se afiava na pedra da morte. Era preciso lembrar que usariam todos os recursos para que as regras do jogo fossem cumpridas: até onde poderia chegar o ódio por aquele que viera humilhálos, irônico, provocativo, tumultuando a partida? (TELLES, 2007, 121, grifo da autora).

Finalmente, o terceiro ponto destacado por Vernant (1988) seria a zona de opacidade entre as personagens. Assim, o que as personagens perdem no entendimento é recuperado pelo leitor. Disso tudo, fica claro que a incomunicabilidade entre as duas personagens centrais do conto contribui fortemente para mensagem trágica logo, para a ironia trágica. E, assim:

No próprio momento em que vê os protagonistas aderirem exclusivamente a um sentido e, nessa cegueira, dilacerarem-se ou perderem-se, o espectador deve compreender que realmente há dois ou mais sentidos possíveis. A linguagem se torna transparente para ele, e a mensagem trágica comunicável somente na medida em que descobre a ambiguidade das palavras, dos valores, do homem, na medida em que reconhece 0 universo como conflitual [...] (VERNANT, 1988, p. 35).

Tudo isso para mostrar como o protagonista não compreende a mensagem passada pelo porteiro, tomando-a somente como mera preocupação de um velho senil pois, afinal, como uma comunidade de velhos debilitados poderiam lhe fazer mal? $\mathrm{Na}$ 
verdade, seria o contrário, ou seja, pela força e pela saúde juvenil seria muito mais fácil o jovem dominar os velhos. Por outro lado, não se deve esquecer que o rapaz chega a uma comunidade pré - estabelecida, com seus costumes e normas, ao invadir de forma audaciosa e orgulhosa esse grupo, o jovem quebra a ordem organizacional. Então, ainda que não haja uma norma sancionada por escrito, tal qual acontece com o decreto escrito expedido pelo rei Creonte, em Antígona, de Sófocles, ainda assim a ordem foi rompida e aquele que rompe com a ordem deve ser castigado exemplarmente.

\section{Considerações finais}

Foi objetivo desse ensaio sobre o conto "A presença" mostrar como os rastros do trágico estavam presentes nessa narrativa breve. Assim, a princípio o que se pretendeu foi fazer um estudo entre os dois gêneros aproximando-os e distanciando-os em suas particularidades, tendo em vista que são gêneros que pertencem a mundos diferentes. Isso foi feito no intuito de trabalhar com um conceito caro ao gênero trágico que é a questão da hybris, ou seja, a desmedida. É por conta do orgulho do herói que acontecerá o seu destino infeliz.

Nesse sentido, é no desequilíbrio interno do caráter do herói, que irá consistir tal desmedida. Nesse momento, vale retomar Aristóteles (2005) e lembrar que o desequilíbrio do herói não se dá por conta de uma falha moral mas sim, por um erro de julgamento ou de conhecimento. Assim, o herói do conto não apresenta características ruins moralmente, ele apenas não consegue discernir sua ação que poderá lhe causa um infortúnio, pois há a zona de opacidade falada por Vernant (1988) e Lesky (2005). Tal opacidade prejudicou seu entendimento e o lançou a um comportamento de orgulho perante os velhos. Ainda de acordo com Vernant (1988), a hybris é um valor negativo dentro do mundo ático bem como vai ser um valor ruim também nessa narrativa do século $\mathrm{XX}$.

Como o recorte do conto é amplo em significação e por sua escolha rigorosa não é de forma alguma feita de modo inocente pelo contista, é possível que haja outras tantas fontes de significação para esse conto que merecem ser estudadas. Para esse final, não deve passar sem nenhum comentário o fato de que o conto, escrito nos anos 70 do século $\mathrm{XX}$, em plena ditadura militar, coloca em evidência dois grupos: os velhos, que querem manter a todo custo a ordem e os jovens que as querem quebrar. Vale a análise, em outro momento, dessa linha de interpretação metafórica de Brasil. Mais uma vez, é o 
trabalho minucioso de escolha do recorte que garante ao conto o poder de se abrir para uma gama de possibilidades que não se esgota nela mesma. Mérito da contista.

\section{Referências}

ARISTÓteles. Poética. In: ARISTÓteleS. HORÁCIO. LONGINO. Poética Clássica. São Paulo: Cultix, 2005.

BRANDÃO. Juanito de Souza. Teatro Grego. Tragédia e Comédia. São Paulo: Editora Vozes, 2009.

CORTÁZAR, Julio. Valise de Cronópio. São Paulo: Perspectiva, 1973.

FREUD, Sigmund. O Estranho. In: FREUD, Sigmund. A história da neurose infantil. Vol. XVII. Rio de Janeiro: Imago, 1976. p. 273-315.

LESKY, Albin. A tragédia grega. São Paulo: Perspectiva, 2010.

PIGLIA, Ricardo. Formas Breves. São Paulo: Companhia da Letras, 2004.

POE, Edgar Allan. Filosofia da composição. In: POE, Edgar Allan. Poemas e Ensaios. São Paulo: Editora Globo, 1999. p. 101-114.

SÓFOCLES. Antígona. Édipo-Rei. In: KURY, Mario da Gama. A trilogia tebana. Rio de Janeiro: Jorge Zahar Editor, 1989.

TELLES, Lygia Fagundes. "A presença”. In: TELLES, Lygia Fagundes. Seminário dos Ratos. São Paulo: Companhia das Letras, 2007. p. 115-121.

TODOROV, Tzvetan. Introdução à Literatura Fantástica. São Paulo: Perspectiva, 2012.VERNANT, Jean-Pierre. Tensões e ambiguidade na tragédia grega. In: VERNANT, Jean -Pierre; VIDAL-NAQUET, Pierre. Mito e tragédia na Grécia Antiga. São Paulo: Brasiliense, 1988. p. 19-40 